\title{
Pemetaan Konten Promosi Digital Bisnis Kuliner kika's Catering di Media Sosial
}

\author{
Yuni Tresnawati ${ }^{1}$ dan Kurniawan Prasetyo ${ }^{2}$ \\ 1,2Universitas Mercu Buana
}

\begin{abstract}
ABSTRAK
Kegiatan promosi adalah salah satu hal terpenting dalam menjalankan sebuah bisnis untuk memasarkan produk/jasa. Sejalan dengan berkembangnya teknologi yang ada saat ini, strategi dalam melakukan pemasaran pun juga mulai berubah ke arah yang lebih modern, yaitu dengan teknologi Internet, atau yang kemudian dikenal dengan istilah digital marketing. Beragam jenis media sosial dan karakteristiknya dapat menjadi alternatif untuk melakukan promosi digital bisnis kuliner. Banyaknya kemudahan dan fungsi dalam penggunaan media digital, telah mendorong banyak pengusaha dalam bidang usaha kuliner untuk ikut serta dalam memanfaatkan fasilitas media digital sebagai sarana promosi produk-produknya. Salah satunya adalah dengan menggunakan media sosial sebagai media promosi. Media sosial yang sering digunakan adalah Facebook dan Instagram, berdasarkan survei emarketer yaitu sebesar 87,5\% untuk Facebook dan 69,2\% untuk Instagram, tentang tren penggunaan media sosial. Fakta inilah yang juga disadari oleh Kika's Catering, salah satu bisnis kuliner yang menggunakan media sosial untuk kegiatan promosinya. Namun beragam jenis media sosial yang ada tentu memiliki sifat, karakteristik, ciri khas, konten, bahkan tujuan yang berbeda pula. Menggunakan media sosial yang tidak tepat dapat menyebabkan kegiatan promosi menjadi tidak efektif. Konten promosi menjadi hal penting dalam menggunakan media sosial yang digunakan. Tujuan dari penelitian ini adalah untuk mengetahui dan menganalisis pemetaan konten promosi digital bisnis kuliner di Facebook dan Instagram. Penelitian ini menggunakan metode deskriptif kualitatif. Hasil penelitian menunjukan bahwa beberapa hal yang harus menjadi perhatian dalam melakukan kegiatan promosi digital adalah mendefinisikan target konsumen dan penggunaan konten promosi. Konten yang tepat digunakan pada Instagram adalah visual/image dan hashtag. Sedangkan untuk Facebook adalah photo album, teks, dan fanpage.
\end{abstract}

Kata-kata Kunci: Digital; konten; kuliner; media sosial; promosi

\section{Mapping The Content of Digital Promotion For Culinary Business Kika's Catering on Social Media}

\begin{abstract}
Promotional activities are one of the most important things in running a business to market products/services. In line with the development of existing technology today, the strategy in doing marketing also began to change to modern way, that is with Internet technology, or which became known as digital marketing. Various types of social media and its characteristics can be an alternative to conduct digital promotion in culinary business. Many advantages and functions in the use of digital media, has encouraged many entrepreneurs in the culinary business to participate in utilizing digital media facilities as a means of promotion of its products.Social media that is often used by users as promotion are facebook and Instagram, based on the survey of emarketers, which is 87,5\% for Facebook and 69,2\% for Instagram, about the trend of social media usage. This fact also realized by Kika;s Catering, one of the culinary business which use social media for promotional activities. But each social media have the nature, characteristics, content, even different purposes. Using inappropriate social media can lead to ineffective promotion activities. Promotional content is important in using social media used. This research aims to know and analyze the mapping of digital promotional content of culinary business in Facebook and Instagram. This research uses a descriptive method. Results of this research showed that there are some important things in digital promotion, such as defining target audience and content marketing or promotion. The right content for Instagram is image/ visual content and hashtag. Meanwhile for Facebook is photo album, text, and fanpage.
\end{abstract}

Keywords: Content; culinary; digital promotion; social media

Korespondensi: Yuni Tresnawati, M.Ikom. Universitas Mercu Buana. Jalan Meruya Selatan No.1, Kembangan, Jakarta Barat 11650.Email: yuni.tresnawati80@gmail.com 


\section{PENDAHULUAN}

Berwirausaha kini telah menjadi salah satu pilihan mata pencaharian terbaik yang menjadi pilihan para pencari kerja. Bukan hanya karena lapangan kerja yang masih sangat kurang untuk memenuhi kebutuhan masyarakat, namun juga disebabkan karena wirausaha dapat menjanjikan penghasilan yang besar. Statistik mengenai jumlah tenaga kerja Indonesia menunjukan data bahwa 99,5\% tenaga kerja Indonesia bekerja di bidang usaha kecil dan menengah (Kurniawan dalam Jauhari, 2010). Salah satu jenis usaha yang menjanjikan adalah usaha di bidang kuliner. Usaha kuliner dewasa ini sangat marak bermunculan, diiringi dengan budaya konsumtif masyarakat, secara umum publik memposisikan diri mereka sebagai konsumen. Oleh karena itu peluang usaha yang sesungguhnya akan muncul dengan sendirinya dan dapat dimanfaatkan untuk keperluan bisinis. Apalagi dalam dunia bisnis bidang kuliner di Indonesia yang terasa semakin berkembang dan terus berkembang belakangan ini, dapat dilihat dari semakin banyaknya bisnis kuliner yang bermunculan. Peluang usaha kuliner ini memang sangat bagus untuk para pelaku bisnis, baik pebisnis mahir maupun pelaku bisnis pemula.

Salah satu hal terpenting dalam menjalankan sebuah bisnis adalah kegiatan promosi untuk memasarkan produk/jasa. Promosi menjadi sebuah hal yang penting untuk dilakukan dalam mengembangkan bisnis, untuk meningkatkan brand awareness produk di masyarakat, atau untuk menjaga eksistensi produk tersebut di pasaran. Promosi menurut Boone dan Kurtz (2005: 129) adalah proses menyebarkan informasi, membujuk dan mempersuasi sebuah keputusan pembelian. Kegiatan promosi merupakan bagian dari strategi pemasaran yang dibutuhkan usaha bisnis, baik usaha kecil maupun menengah.

Sejalan dengan berkembangnya teknologi yang ada saat ini, strategi dalam melakukan pemasaran pun juga mulai berubah ke arah yang lebih modern. Jika dulu hanya menggunakan media promosi seperti surat kabar, majalah, radio, ataupun televisi, kini pemasaran sudah dilakukan dengan teknologi Internet, atau yang kemudian dikenal dengan istilah digital marketing. Sedikitnya terdapat empat manfaat digital marketing dalam memaksimalkan suatu bisnis, diantaranya adalah menghemat biaya promosi, menjangkau pasar yang lebih luas, sebagai sarana untuk meningkatkan penjualan, dan menjadi sarana penghubung yang baik dengan konsumen.

Banyaknya kemudahan dan fungsi dalam penggunaan media digital, telah mendorong banyak pengusaha dalam bidang usaha kuliner untuk ikut serta dalam memanfaatkan fasilitas media digital sebagai sarana promosi produk- 
produknya. Salah satunya adalah dengan menggunakan media sosial sebagai media promosi mereka. Beragam jenis media sosial dan karakteristiknya dapat menjadi alternatif untuk melakukan promosi digital bisnis kuliner. Media sosial yang sering digunakan oleh pengguna sebagai media promosi antara lain Facebook, Twitter, dan Instagram. Menggunakan media sosial adalah langkah yang paling praktis untuk mempromosikan produk dari suatu bisnis, termasuk bisnis kuliner.

Hal ini didukung dalam sebuah survei yang terangkum dalam website "We Are Social", menyatakan bahwa pengguna media sosial aktif di seluruh duni saat ini mencapai 2,2 miliar. Pertumbuhan yang signifikan ditunjukan oleh pengguna media sosial melalui platform mobile.

Adapun pengguna jenis tersebut meningkat hingga 23,3 persen (We Are Social, 2015).

Menurut data yang dihimpun oleh lembaga survei yang berbasis di Amerika Serikat, yaitu Emarketer, tren akses Facebook di Indonesia sebesar $87,5 \%$ dilakukan pada perangkat ponsel, dengan para penggunanya yang mayoritas berusia 16-35 tahun. Berdasarkan data Emarketer, setelah Facebook, tren penggunaan media sosial selanjutnya paling banyak adalah Instagram (Emarketer: 2016).

Namun beragam jenis media sosial yang ada tentu memiliki sifat, karakteristik, ciri khas, konten, bahkan tujuan yang berbeda pula.
Menggunakan media sosial yang tidak tepat dapat menyebabkan kegiatan promosi menjadi tidak efektif. Isi (konten) promosi menjadi hal penting dalam memilih media sosial yang akan digunakan. Kecenderungan kesalahan pelaku bisnis dalam menggunakan media sosial sebagai media promosi adalah tidak mengoptimalkan jenis media sosial itu, atau dengan menyamakan isi (konten) promosi yang sama menggunakan media sosial yang berbeda, padahal setiap media sosial memiliki kelebihan dan kekurangan masing-masing terhadap suatu konten (pesan) komunikasi yang disampaikan, termasuk pesan-pesan promosi.

Sebagai contoh media sosial Instagram, yang memiliki keistimewaan pada kekuatan visual (gambar), maka konten promosi yang tepat untuk instagram adalah pesan-pesan yang menggunakan bahasa visual melalui foto atau gambar. Cara berpromosi melalui Instagram pun sangat unik dan variatif. Kegiatan promosi dan pesan yang disampaikan tidak akan efektif jika pelaku bisnis menggunakan pesan teks berupa deskripsi dan complex explanation (penjelasan lengkap) pada media Instagram, begitu pula dengan Facebook dan Twitter. Ketiga media sosial ini memiliki kekuatannya masing-masing dalam menyampaikan pesanpesan promosi. Berdasarkan hal tersebut maka tujuan dari penelitian ini adalah mengetahui dan menganalisis pemetaan konten promosi digital 
bisnis kuliner di media sosial Instagram dan Facebook.

Pesatnya perkembangan teknologi komunikasi sejalan dengan tergesernya peran media konvensional. Media baru, sebagai salah satu media yang berkembang mampu memadupadankan teks, suara, gambar, dan video dengan menggunakan teknologi komputer yang berbeda dari media tradisional. Menurut Flew (2005) media baru (new media) adalah terminologi yang menjelaskan tentang teknologi komunikasi digital yang terkomputerisasi dan terhubung ke dalam jaringan. Contoh dari media baru adalah Internet. Adapun program televisi, film, surat kabar, dan jenis media cetak lain tidak termasuk ke dalam kategori media baru.

Munculnya media baru memberikan dampak dan pengaruh yang besar bagi kehidupan sosial manusia. Media baru dapat berperan dalam merubah pola kehidupan masyarakat, baik dari aspek budaya, cara berpikir, dan aspek-aspek lain dalam kehidupan manusia. Selanjutnya menurut Biagi (2005) terminologi media digital dimaksudkan untuk menjelaskan segala bentuk komunikasi melalui media yang memadupadankan teks, gambar, suara dan video melalui penggunaan teknologi komputer.

New media hadir dari inovasi media lama yang dinilai tidak cukup relevan dengan perkembangan teknologi di era saat ini. Bila di era lama audience menggunakan satu benda untuk satu fungsi, missal koran untuk dibaca, televisi untuk dillihat, radio untuk didengar, maka di era baru, yakni era new media, dalam satu benda kita dapat melakukan banyak hal sekaligus (Prihantoro: 2016).

Awal perkembangan media baru ini, sebelumnya dianggap sebagai perkembangan dari media audiovisual yang sudah banyak digunakan sebelumnya, namun memiliki aspek yang berbeda dari sudut produksi, distribusi, dan bentuk dasar, jika dibandingkan dengan media pandang-dengar (Mc. Quail, 1987:18). Selanjutnya, media baru dianggap mampu menyambungkan perbedaan antara garis batas kegiatan komunikasi pribadi dengan komunikasi publik. Bahkan dengan kegunaan media semacam itu dapat dimanfaatkan secara bersamaan untuk kepentingan pribadi dan publik. Fenomena tersebut tentunya akan memberikan pengaruh bukan saja terhadap batas-batas tiap media yang berbeda, namun juga terhadap batas-batas antara peran institusi media (Mc.Quail, 1987: 17-18).

Internet saat ini telah menghasilkan beberapa bentuk baru bagi interaksi sosial manusia, termasuk kegiatan komunikasi. Hal ini disebabkan karena karakteristik Internet yang bersifat tersebar dan mudah digunakan melalui Jejaring sosial (social-networking) seperti Facebook, Twitter, dan Myspace. Hal ini telah 
menciptakan cara baru dalam hal berinteraksi dan berkomunikasi. Menurut Corole Hughes (1999) generasi pertama di abad 21 hidup dan berkembang dengan adanya keberadaan Internet yang semakin meluas. Hal ini yang membawa konsekuensi terhadap beberapa wilayah seperti privasi dan identitas pribadi, serta adanya distribusi yang tak terkontrol atas konten-konten yang memiliki hak cipta.

Media sosial merupakan sebuah media online, yang para penggunanya dapat dengan mudah untuk ikut serta masuk ke dalam beberapa aktivitas dan interaksi yang dilakukan di media sosial tersebut. Aktivitas yang dilakukan pengguna di media sosial tidak menutup kemungkinan untuk melakukan kegiatan pertukaran informasi. Pemasaran dapat memanfaatkan informasi yang saling ditukarkan di media sosial untuk menginformasikan mengenai produk atau jasa atau merek mereka.

A. M Kaplan, dan M. Haenlein (2010: 62) mendefinisikan media sosial sebagai aplikasi berbasis Internet yang dibangun melalui teknologi Web 2.0 dan memungkinkan adanya penciptaan dan pertukaran user generated content. Masih dari sumber yang sama A. M. Kaplan, dan M. Haenlein menjelaskan bahwa Web 2.0 adalah istilah yang pertama kali digunakan untuk menggambarkan cara baru dalam pengembangan perankat lunak dan pengguna akhir mulai memanfaatkan World
Wide Web (www). Definisi lain menyebutkan pengertian media sosial menurut David Meerman Scott (2014):

"Social media provides the way people share ideas, content, thoughts, and relationship online. Social media differ from so called "mainstream media" in that anyone can create, comments on, and add to social media content. Social media can take the form of text, auido, video, maps, and communities".

Sementara itu definisi yang lebih teknis disampaikan A. M. Kaplan dan M. Haenlein bahwa media sosial adalah sebagai sebuah kelompok aplikasi berbasis Internet yang dikembangkan di atas dasar ideologi dan teknologi Web 2.0 dan yang memungkinkan terciptanya pembuatan dan pertukaran user generated content (Adam: 2014).

Definisi lain menyebutkan bahwa media sosial merupakan kombinasi antara elemen dunia maya, dan juga kekuatan komunitas yang dibangun pada jejaring sosial. Kegiatan komunikasi di dalamnya menyebabkan efek "power" khusus melalui berbagai media interaksi yang disajikan dalam bentuk teks, gambar, foto, audio juga video. (Juju \& Sulianta, 2010)

Beberapa hal yang menjadi karakter media sosial, menurut Gustam (2015), antara lain: 1). partisipasi, yang mendorong umpan balik dan kontribusi dari setiap orang yang menggunakannya, sehingga menipiskan batasan antara media dan publik/audiens, 2). 
keterbukaan, media sosial bersifat terbuka bagi setiap partisipasi yang dilakukan melalui berbagai saluran komunikasi, 3). perbincangan, yang memungkinkan terjadinya perbincangan di antara para pengguna, 4). komunitas, komunitas dapat secara cepat dan efektif berkomunikasi mengenai berbagai isu/kepentingan, dan 5.) keterhubungan, media mampu menyediakan keterhubungan antara pengguna, melalui berbagai fasilitas tautan (links) ke website.

Menurut Zarella (2010) media sosial merupakan paradigma media baru dalam lingkup industri pemasaran. Weber juga menyebutkan bahwa media konvensional seperti TV, radio, dan koran sejauh ini hanya memfasilitasi komunikasi satu arah sementara media sosial komunikasinya bersifat dua arah sehingga memungkinkan setiap pengguna dapat melakukan kegiatan publikasi dan berkontribusi melalui percakapan dalam jaringan (online). Media sosial adalah platform yang mampu memfasilitasi berbagai macam aktivitas dan berbasis komunitas. Media sosial dapat memfasilitasi komunikasi. Pemakai dapat membuat dan berbagi konten. Dalam penelitian ini, jenis media sosial yang digunakan adalah media sosial Facebook dan Instagram.

Berbagai fitur yang tersedia di media sosial telah membuat akses berbagi informasi dan berinteraksi menjadi lebih mudah, Namun banyaknya media sosial ke dalam aktivitas promosi sepertibrandingjugamenjadi tantangan bagi perusahaan. Media sosial menuntut brand tersebut untuk terus memperhatikan kecepatan informasi dan kuatnya interaksi suatu merek dengan pasarnya. Jika tidak terus diperbaharui dan lambat dalam memberikan respons kepada khalayak, maka pengelolaan media sosial yang buruk dapat memberikan pandangan negatif bagi merek tersebut. Media sosial yang tidak dikelola dengan baik dan menarik malah akan berpotensi menurunkan kepercayaan konsumen (Saepudin \& Darmawati: 2016).

\section{Setelah era Search Engine Optimization} (SEO), muncul lah Web 2.0 atau yang lebih popular disebut dengan social media, pada tahap selanjutnya memunculkan konsep baru yaitu SMO (Social Media Optimization). Pada prinsipnya, menggabungkan teknik SEO dan SMO untuk kegiatan online marketing akan memberi dampak yang luar biasa (Lasmadiarta, 2011)

Facebook telah mengembangkan beragam aplikasi yang dapat dimanfaatkan para pengguna, termasuk digunakan untuk kepentingan marketing online yang mendukung usaha dan pekerjaan, antara lain: menjual atau membeli barang (Muklason dan Aljawiy, 2011).

Jejaring sosial seperti Facebook ini membuka peluang untuk melakukan aktivitas marketing dengan cara dan berbiaya relatif lebih mudah dan murah (Lasmadiarta, 2011). 
Kegiatan marketing dan bisnis melalui jejaring sosial Facebook dapat dikategorikan sebagai E-Commerce. Penjelasan lebih lanjut, Facebook marketing merupakan aktivitas marketing yang menggunakan fasilitas Facebook dengan maksud menjalin relasi dengan pelanggan (customer relationship) demi meningkatkan penjualan (sales). Selain Facebook, media sosial lain yang kini populer adalah Instagram. Instagram adalah aplikasi penyedia layanan berbagi foto, lalu menyebarkannya di media sosial seperti Facebook, Twitter, dan lainnya. Adapun, Instagram berasal dari pengertian keseluruhan fungsi aplikasi ini. Secara harafiah, kata "Instagram" berasal dari dua kata yaitu "Insta" dan "gram". Artinya "instan" yaitu berarti cepat atau mudah. Sedangkan kata "gram" diambil dari "telegram" yang berarti sebagai media pengirim informasi yang sangat cepat.

Dari penggunaan dua kata tersebut, arti dan fungsi sesungguhnya dari Instagram yaitu sebagai salah satu media untuk memproduksi foto dan mengirimkannya dalam waktu yang sangat cepat. Saat ini Instagram bertambah fungsinya menjadi wadah para pebisnis untuk memasarkan produk dan jasanya. Produk online shop yang dikomunikasikan melalui Instagram mulai dari fashion, hingga kuliner.

Internet marketing atau e-marketing menurut Strauss dan Frost (2001) adalah kegiatan penggunaan data dan aplikasi elektronik yang dimanfaatkan untuk melakukan perencanaan dan pelaksanaan konsep, distribusi, promosi, dan penetapan harga untuk menciptakan transaksi yang memuaskan tujuan, baik individu maupun organisasi.

Sedangkan, Internet marketing adalah bentuk usaha dari pemasar secara langsung untuk memasarkan produk dan jasanya serta menjalinrelasi dengan konsumen melalui media internet. Internet merupakan situs publik yang menghubungkan seluruh pengguna komputer di seluruh dunia ke dalam suatu wadah informasi yang sangat luas dan besar (Kotler: 2008) Sedangkan pengertian yang diutarakan oleh Boone dan Kurtz (2005) tentang e-marketing adalah sebagai salah satu komponen dalam e-commerce meliputi, strategi produksi, distribusi, promosi barang dan jasa kepada konsumen melalui pasar Internet.

Konten promosi pada dasarnya merupakan pesan-pesan komunikasi yang bersifat persuasif dan ditujukan kepada publik atau dalam hal ini konsumen, dengan tujuan pengenalan produk kepada konsumen. Pesan yang dimaksud adalah seperangkat simbol verbal dan/atau nonverbal yang mewakili maksud sumber tadi. Pesan terdiri dari makna, simbol yang dipakai untuk mewakili makna, serta bentuk atau organisasi pesan (Mulyana: 2000). Pesan mengandung informasi yang disampaikan oleh pengirim 
pesan (pemasar) pada publiknya (konsumen).

Dalam pemasaran, pemasar dapat menyajikan pesan untuk menarik konsumen. Pesan yang dikemas dengan cara yang menarik, akan lebih mudah diingat.

Terdapat jenis komunikasi yaitu komunikasi verbal dan non verbal. Kegiatan Komunikasi verbal merupakan salah satu jenis komunikasi yang dilakukan untuk menyampaikan informasi bisnis kepada pihak lain/konsumen, baik secara tertulis (written) maupun lisan (oral). Kegiatan komunikasi yang efektif bergantung pada keterampilan komunikator dan komunikan dalam memahami pesan. Untuk mengirim pesan, komunikator dapat menggunakan komunikasi dalam bentuk tulisan maupun lisan. Sementara untuk menerima pesan, komunikan dapat menggunakan pendengaran dan bacaan (Purwanto: 2006).

Adapun pesan nonverbal adalah pesan yang disampaikan selain menggunakan bahasa. Definisi lain disebutkan dalam Mulyana (2000), bahwa:

"Komunikasi nonverbal meliputi semua stimulus (kecuali stimulus verbal) dalam sebuah setting komunikasi, yang dihasilkan oleh individu, dan digunakan oleh individu serta mempunyai nilai potensial bagi setip aktor komunikasi”.

Efektivitas pesan bisnis tergantung pada struktur dan isi pesan. Prinsipnya, sebuah pesan sebaiknya mampu menarik perhatian (attention), minat (interest), menumbuhkan keinginan (desire), dan mendorong tindakan (action) atau model AIDA. Namun pada kenyataannya, tak semua pesan mampu mengajak konsumen untuk melalui semua tahap mulai dari munculnya kesadaran sampai kepada tindakan pembelian, tetapi kerangka kerja AIDA tersebut menjelaskan kualitas yang diinginkan dari setiap komunikasi (Kotler: 2005).

Berdasarkan hal yang telah dipaparkan di atas maka tujuan dari penelitian ini adalah untuk mengetahui dan menganalisis bagaimana pemetaan konten promosi digital bisnis kuliner Kika’s Catering di Facebook dan Instagram.

\section{METODE PENELITIAN}

Tipe penelitian ini adalah deskriptif. Penelitian deskriptif dilakukan untuk menjabarkan (analitis) dan memadukan (sintesis). Pada sebuah penelitian deskriptif, data yang diperoleh bukan dalam bentuk angka melainkan dalam bentuk kata-kata yang diambil dari pernyataan. Penelitian deskriptif bertujuan untuk memaparkan situasi, dan tidak bermaksud untuk mencari atau pun menjelaskan hubungan,tidak juga untuk menguji hipotesis atau membuat prediksi (Rakhmat, 2002: 22). Pada penelitian ini peneliti menjabarkan secara deskriptif temuan-temuan penelitian mengenai pebisnis kuliner dengan cara memetakan konten-konten promosi digital melalui media sosial. 
Dalam penelitian ini, peneliti bertindak sebagai pengamat sekaligus terjun langsung ke lapangan guna mencari data yang diperlukan dengan cara mewawancarai pihak-pihak yang terkait. Selanjutnya, dipaparkan situasi yang ada.

Adapun metode pengumpulan data yang digunakan dalam penelitian ini yaitu: 1) wawancara, yang diwawancarai yaitu para pebisnis usaha kuliner yang melakukan promosi di media sosial. Narasumber dalam penelitian ini adalah Ibu Agustina Purwanti, pemilik usaha kuliner Kika's Catering, yang mengelola sendiri promosi produknya melalui media sosial Instagram dan Facebook, 2) observasi, dalam konteks ini, maka peneliti melakukan observasi pada akun-akun media sosial bisnis kuliner, yaituusaha kuliner Kika's Catering, yang mengelola sendiri promosi produknya melalui media sosial Instagram dan Facebook, 3) studi dokumentasi digunakan untuk menelusuri data historis dan kontekstual yang ada di media sosial bisnis kuliner Kika’s Catering.

Pada prinsipnya, proses analisis data dilakukan secara bersama-sama dengan proses pengumpulan data. Adapun penjelasan mengenai teknik analisis data, mengacu pada pernyataan Miles dan Huberman yang menyebutkan terdapat tiga kegiatan yang dilakukan secara bersamaan, yaitu: reduksi data, penyajian data, dan penarikan kesimpulan (verifikasi) (Basrowi, 2008: 209).

Subjek dalam penelitian ini adalah Ibu Agustina Purwanti, yang merupakan owner atau pemilik dari bisnis di bidang kuliner Kika's Catering. Sedangkan objek penelitian adalah akun Facebook dan Instagram Agustina Puwanti, yang menjadi media dalam mempromosikan produk-produk miliknya.

\section{HASIL DA PEMBAHASAN}

Kika's Catering adalah salah satu brand yang bergerak di bidang kuliner, yang merupakan bisnis small medium enterprise (SME) atau dikenal dengan UMKM (Usaha Mikro Kecil Menengah). Produk-produk yang dihasilkan adalah berbagai makanan jadi berupa kue tradisional seperti risoles, lemper, puding, cake, dan masakan khas Yogyakarta seperti gudeg, ayam bakar Yogya, sambal goreng, rendang Jawa, dan sebagainya.

Pemilik bisnis ini bernama Agustina

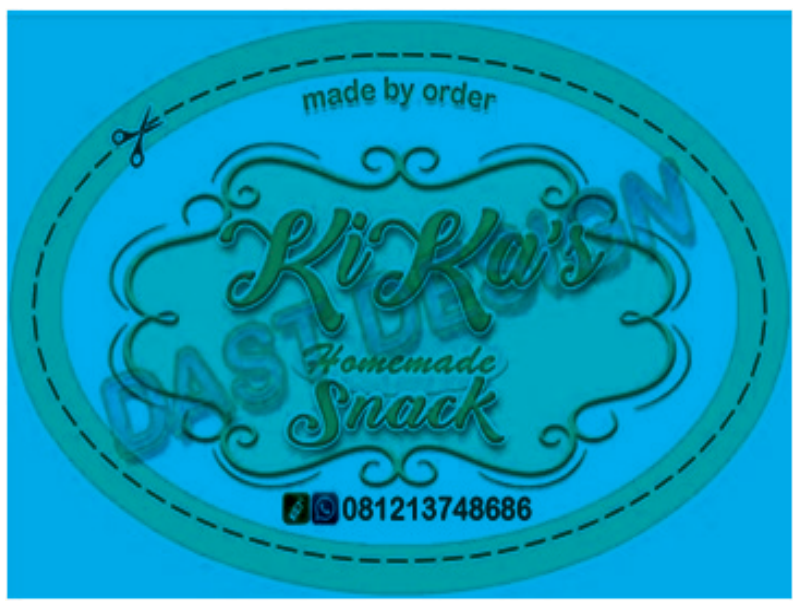

Sumber: Dokumen Pribadi Agustina Purwanti, 2017

Gambar 1.Logo Kika's Catering 
Purwanti. Dalam menjalankan bisnisnya, pemilik Kika's Catering ini memanfaatkan media sosial sebagai media promosi untuk memasarkan produknya. Media sosial yang digunakan adalah Facebook dan Instagram pribadi milik Agustina Purwanti, yang aktif melakukan kegiatan promosi di media sosial sejak tahun 2016, dengan jumlah followers sebanyak 577 orang untuk akun Instagram, sedangkan untuk Facebok berjumlah 953 orang.

Digital marketing atau yang lebih dikenal dengan istilah e-marketing, merupakan bentuk usaha dari produsen untuk memasarkan produk dan jasanya serta membangun hubungan dengan pelanggan melalui media Internet. Bentuk pemasaran ini pada dasarnya merupakan bagian dari pemasaran langsung (Kotler, 2008). Definisi lain menyebutkan promosi digital adalah penggunaan data dan aplikasi elektronik untuk perencanaan dan pelaksanaan konsep, distribusi, promosi, dan penetapan harga untuk mengadakan pertukaran yang memuaskan tujuan individu dan organisasi (Strauss dan Frost, 2001).

Berdasarkan hasil wawancara dan observasi dengan subjek penelitian, Agustina Purwanti selaku pemilik bisnis Kika's Catering menggunakan media sosial Facebook dan Instagram sebagai media dalam melakukan kegiatan promosi digital. Pemilihan dua jenis media sosial ini didasarkan pada: (1) audience;
(2) konten.

Audience merupakan hal penting yang harus ditentukan dengan jelas ketika melakukan kegiatan pemasaran. Target pasar atau konsumen yang terdefinisi dengan baik akan memengaruhi sukses tidaknya kegiatan pemasaran yang dilakukan, termasuk juga ketika melakukan promosi digital. Terkait hal tersebut Agustina Purwanti selaku pemilik bisnis Kika's Catering menyampaikan alasannya menggunakan media sosial Facebook dan Instagram sebagai berikut: "Target konsumen paling banyak pengguna Facebook dan Instagram. Selain itu di Facebook ada akun natural cooking club (Group atau Fanpage untuk media promosi), kalau Instagram ada foodbloger, intinya meluaskan jaringan"(Purwanti, 2017)

Target pasar atau konsumen dari Kika's Catering adalah teman-teman dari pemilik bisnis itu sendiri. Agustina Purwanti memilih Facebook dan Instagram untuk kegiatan promosi karena mayoritas target konsumen bisnisnya aktif menggunakan media sosial tersebut. Oleh karena itu Agustina merasa tepat menggunakan Facebook dan Instagram untuk meluaskan jaringan pemasaran bisnisnya.

Selain mendefinisikan target konsumen dengan jelas, penggunaan konten juga merupakan hal yang penting dalam kegiatan promosi digital. Content marketing adalah salah satu dari bentuk internet marketing di mana tekniknya adalah dengan membentuk dan mendistribusikan konten yang bermanfaat dan 
relevan yang bertujuan untuk menarik perhatian konsumen (Darmawan, 2015). Berikut penjelasan Agustina Purwanti selaku pemilik bisnis Kika's Catering:

"Konten promosi dalam bentuk foto produk serta deskripsi produk, tips memasak, dan testimoni dari konsumen. Konten ini saya rasa lebih cocok dipromosikan lewat Instagram dan Facebook." (Purwanti, 2017)

Konten promosi yang dibuat dan didistribusikan oleh Kika's Catering adalah konten dalam bentuk visual berupa foto produk dan teks berupa deskripsi produk, bahan-bahan pembuatnya, tips memasak, serta testimoni dari pelanggan atau konsumen. Berdasarkan strategi konten tersebut, maka Agustina Purwanti memanfaatkan media sosial Facebook dan Instagram sebagai media promosi digital bisnis kulinernya.

Instagram merupakan salah satu aplikasi media sosial berbagi foto yang mengusung konsep platform sosial yang memungkinkan penggunanya berinteraksi dengan foto dan video karya mereka. Dalam media sosial Instagram memungkinkan penggunanya mengunggah dan mengedit untuk mempercantik hasil foto dan video sebelum diunggah. Oleh karena itu, Instagram bisa dimanfaatkan pebisnis sebagai media promosi digital, yaitu kegiatan promosi yang menggunakan media online marketing (e-marketing).

Promosi itu biasanya dilakukan melalui testimoni kesaksian dari konsumen yang sudah pernah membeli produk, biasanya konsumen memberikan komentar atas produk yang telah dibelinya itu, lalu merekomendasikan produk yang dia beli kepada orang lain di media sosial Instagram miliknya. Kemudian ada juga yang menggunakan cara endorse sebagai usaha melakukan promosi.

Mengutip dari Sri Dwi Fajarini (2016) tentang promosi penjualan melalui Instagram, promosi mendorong konsumen untuk melakukan pembelian dengan mengimingimingi insentif. Insentif digunakan dalam penjualan untuk mempersuasi calon konsumen agar melakukan pembelian. Penggunaan insentif dapat berupa pemberian diskon atau sale. Dengan memanfaatkan fasilitas update pada Instagram, para pelaku bisnis online dapat melakukan promosi penjualan. Mereka dapat menyampaikan informasi yang berupa foto bareng dengan diberikan penjelasan singkat baik dari bahan, ukuran, harga, dan lain sebagainya. Para pelaku bisnis online memanfaatkan fitur posting untuk menginformasikan foto dan penawaran kepada khalayak.

Sejalan dengan hal tersebut di atas, Agustina Purwanti selaku pemilik bisnis Kika's Catering menyampaikan paparannya tentang konten promosi di Instagram sebagai berikut: "Konten promosi di Instagram dalam bentuk foto makanan, sudah bisa menunjukan rasa, aroma, dan tekstur makanan itu, tanpa 
harus ada konten lain seperti teks atau video. Itulah yang menjadikan keunggulan Instagram untuk media promosi"(Purwanti, 2017).

Selain itu, Agustina Purwanti menambahkan penjelasannya sebagai berikut:

"Kalau di Instagram itu ada foodbloger, yang membantu saya meluaskan jaringan bisnis saya, yang bisa dengan mudah diakses oleh konsumen lewat fitur hashtag di Instagram. Saya juga pake strategi endorser kalau promosi di Instagram" (Purwanti, 2017).

Berdasarkan hasil wawancara dan observasi pada bisnis kuliner Kika's Catering, maka pemetaan konten promosi digital di media Instagram antara lain: 1). visual/image, Instagram memiliki kekuatan stopping power yang lebih kuat dibandingkan dengan media sosial lain karena terfokus dengan image/visual. Konten visual lebih menarik dan mudah untuk memengaruhi orang lain. Selain itu konten image/visual juga jauh lebih mudah dicerna oleh audiens dibandingkan teks. Instagram adalah media sosial yang menggunakan gambar sebagai konten utama. Sebab itu lah, Instagram menyediakan berbagai macam jenis efek dan fitur yang unik untuk diterapkan pada gambar yang akan diupload. Jadi pengguna tidak perlu lagi menggunakan aplikasi lain untuk proses editing foto yang akan di-upload. Hal ini tentu sangat membantu dalam kegiatan promosi di media sosial, khususnya bisnis kuliner, yang produk utamanya adalah makanan atau minuman, sehingga dengan mempromosikan produk lewat foto makanan di Instagram, akan mewakili informasi tentang rasa, tekstur, bahkan aroma makanan yang dipromosikan kepada konsumen, 2). hashtag, Seperti hal nya sebuah keyword dalam search engine, adapun fungsi hashtag pada Instagram yaitu membantu konsumen untuk dapat langsung mencari topik yang ingin dilihat. Hashtag membantu dalam mempromosikan produk bagi pemilik bisnis kuliner. Dengan membubuhkan hashtag pada caption sebuah gambar produk yang diunggah atau dengan cara membuat hashtag unik dan hanya dimiliki suatu produk tertentu. Mencantumkan hashtag yang tepat akan membantu mempercepat proses penyebarluasan informasi mengenai produk kuliner.

Disisi lain, terdapat kesulitan yang biasanya dirasakan oleh para pemilik bisnis yang melakukan kegiatan berpromosi online atau pemilik onlineshop adalah ketika akun Instagram sebagai media untuk berpromosi dan berjualan belum banyak diketahui orang. Ini artinya followers yang dimiliki akun Instagram masih sedikit. Kenyataan ini juga salah satu kendala yang dimiliki Kika’s Catering. Agustina Purwanti menggunakan akun media sosial pribadinya untuk melakukan kegiatan promosi, di mana akun tersebut hanya memiliki 577 followers, yang hanya terbatas pada teman dan keluarga Agustina Purwanti. Hal ini mungkin akan memudahkan pemasaran produk dalam 


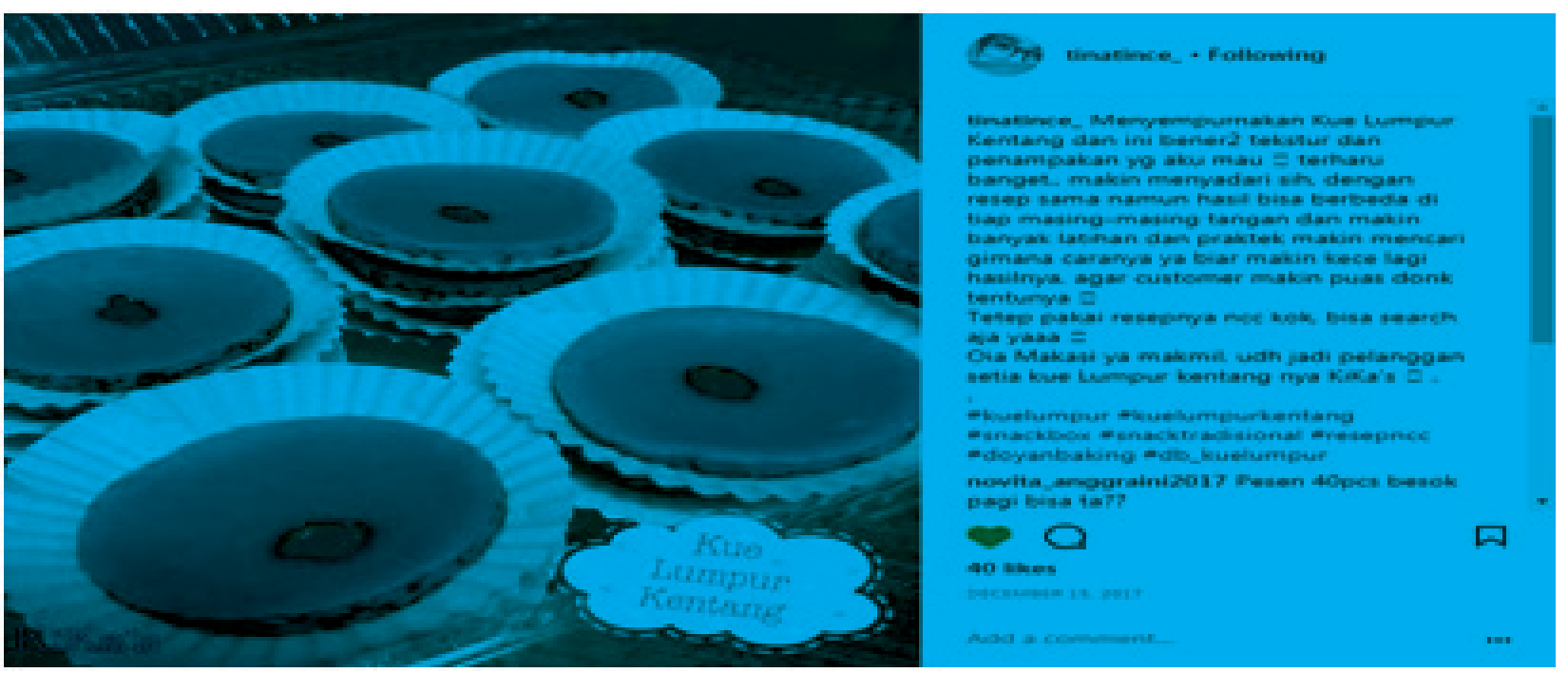

Sumber: Instagram, 2018

\section{Gambar 2 Konten Promosi Kika's Catering di Instagram}

jangka pendek, namun bisnis kuliner ini tidak bisa berkembang jika followers-nya terbatas. Padahal kekuatan yang dimiliki oleh Instagram salah satunya adalah jumlah followers dan komentar yang diterima oleh pemilik akun Instagram (Listiani, 2016).

Facebook merupakan media sosial yang paling banyak digunakan oleh masyarakat Indonesia, maka Facebook dapat menjadi sebuah media promosi produk yang potensial. Selain itu, Facebook menyediakan wadah untuk bertemu dan berkomunikasi antara seorang pengguna dengan pengguna lainnya. Dengan semakin banyaknya pengguna yang bertemu itulah, Facebook kemudian menawarkan media kepada para pengguna bisnis digital dalam mempromosikan produknya.

Agustina Purwanti selaku pemilik bisnis menyampaikan paparannya tentang konten promosi di Facebook sebagai berikut :

"Di Facebook itu saya gabung di group/komunitas dan fanpage 'natural cooking club', yang menjadi salah satu media promosi saya di Facebook untuk menjangkau konsumen yang lebih luas. Di facebook saya juga pake strategi testimoni produk untuk membangun trust dengan calon konsumen"

Selanjutnya, Agustina Purwanti menambahkan penjelasannya sebagai berikut:

"Kalau di Facebook itu bisa pakai album foto untuk memudahkan konsumen melihat produk-produk yang saya tawarkan”.

Berdasarkan hasil wawancara dan observasi pada bisnis kuliner Kika's Catering, maka pemetaan konten promosi digital di media Facebook antara lain: 1). photo album, walaupun konten image/gambar sudah banyak diterapkan di banyak media sosial, tapi kelebihan konten image/gambar di Facebook adalah detail dan pengorganisasian gambar yang jelas. Tentu 
dari sisi promosi digital, hal ini akan lebih melihat kualitas produk. memuaskan dan memudahkan konsumen dalam

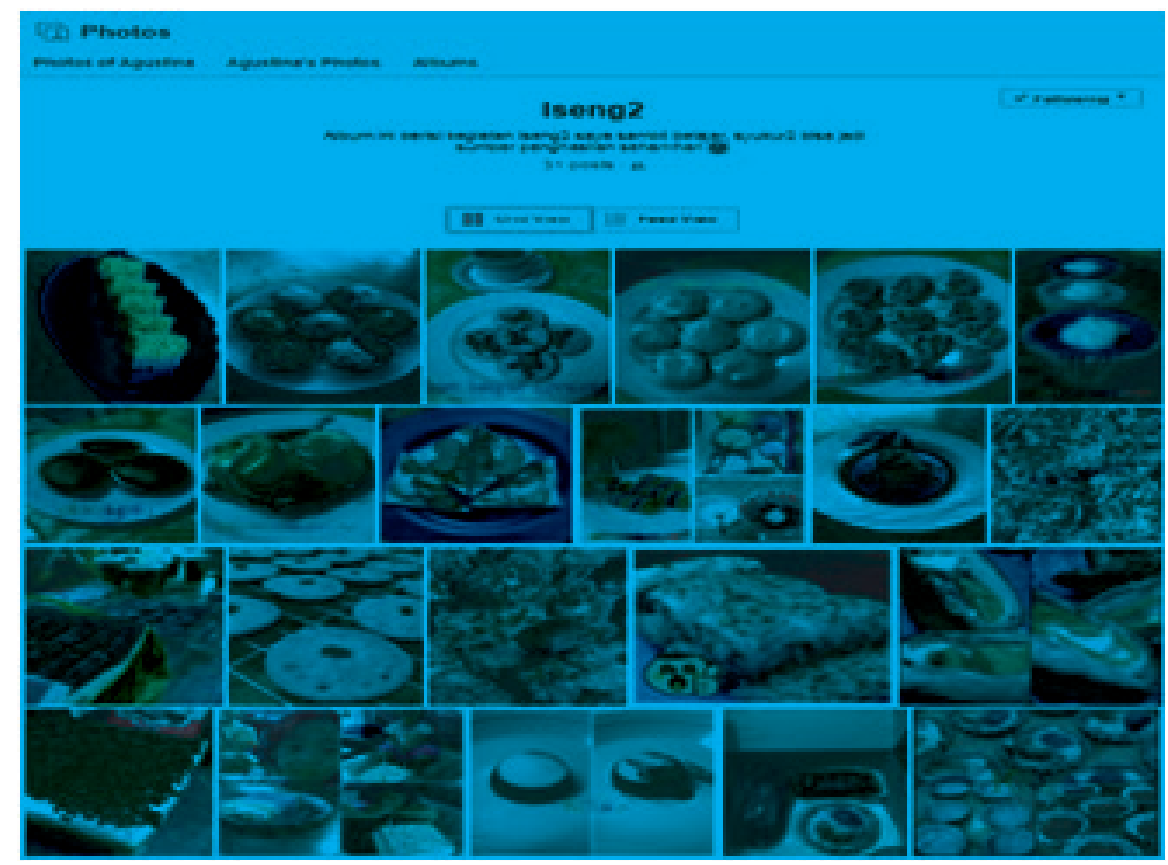

Sumber: Facebook, 2018

\section{Gambar 3 Konten Promosi Album Foto Kika's Catering di Facebook}

2). teks, konten lain yang tepat untuk promosi di media Facebook adalah konten tulisan. Facebook menawarkan fitur posting teks yang tidak terbatas, tidak seperti media sosial Twitter dan Instagram, yang dibatasi jumlah teksnya. Konten teks (tulisan) ini dapat digunakan pebisnis kuliner untuk memaparkan deskripsi produk dengan detail, seperti bahanbahan yang digunakan, tips memasak, hingga testimoni dari para pelanggan yang sudah mencicipi produk yang dipromosikan. 3). fanpage, adalah fitur yang dimiliki Facebook dan dapat dioptimalkan penggunaannya oleh pelaku bisnis digital. Membuat akun fanpage ini syaratnya memiliki akun pribadi di Facebook, yang selanjutnya dapat membuat akun fanpage untuk kegiatan bisnis. Kelebihan dari fanpage memudahkan para konsumen dan calon konsumen dalam mengetahui informasi tentang produk. Tampilan yang ditawarkan oleh fanpage di Facebook ini juga memberikan kesan profesional sehingga memudahkan pebisnis untuk meningkatkan kepercayaan dari calon konsumen. 


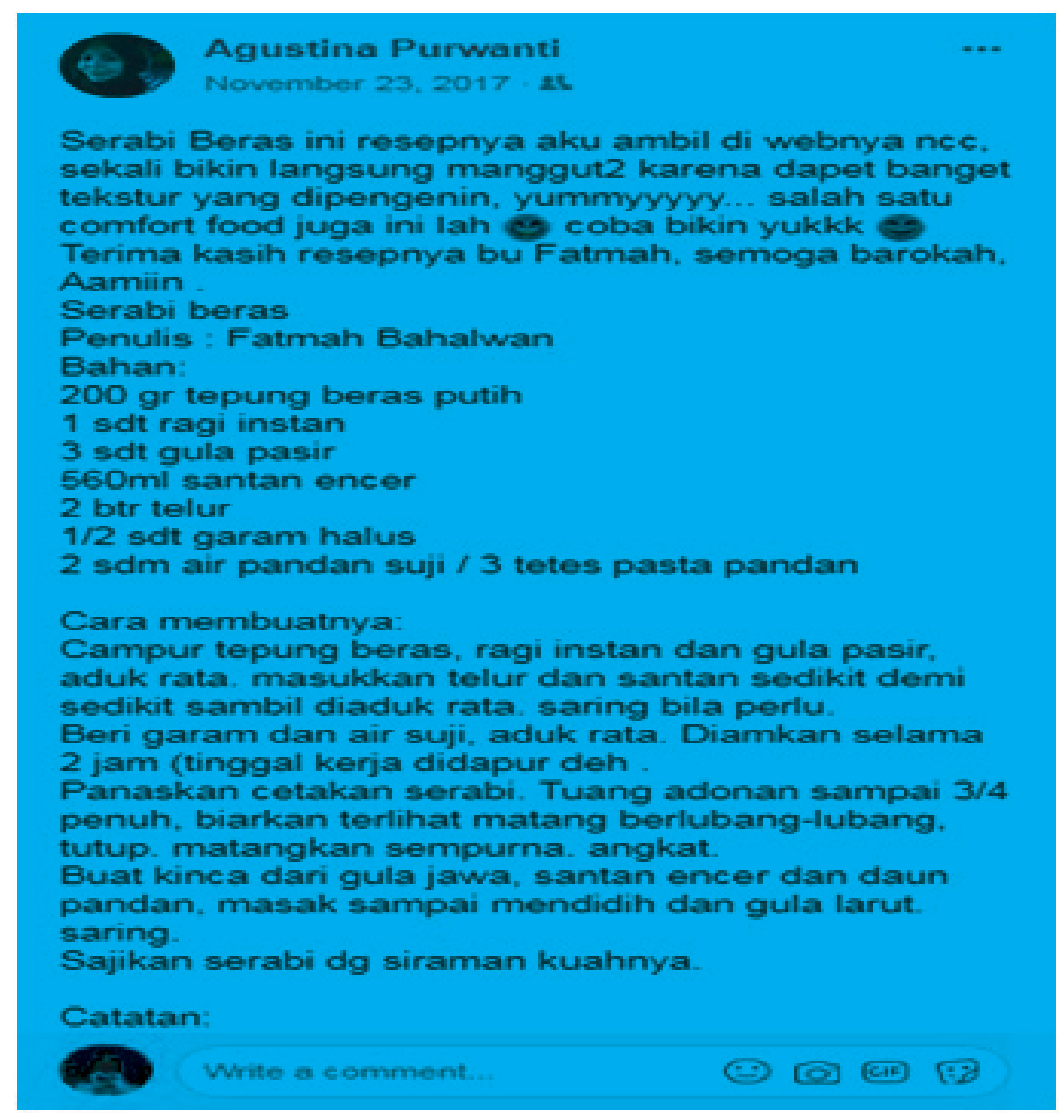

Sumber: Facebook, 2018

\section{Gambar 4 Konten Promosi Teks Kika's Catering di Facebook}

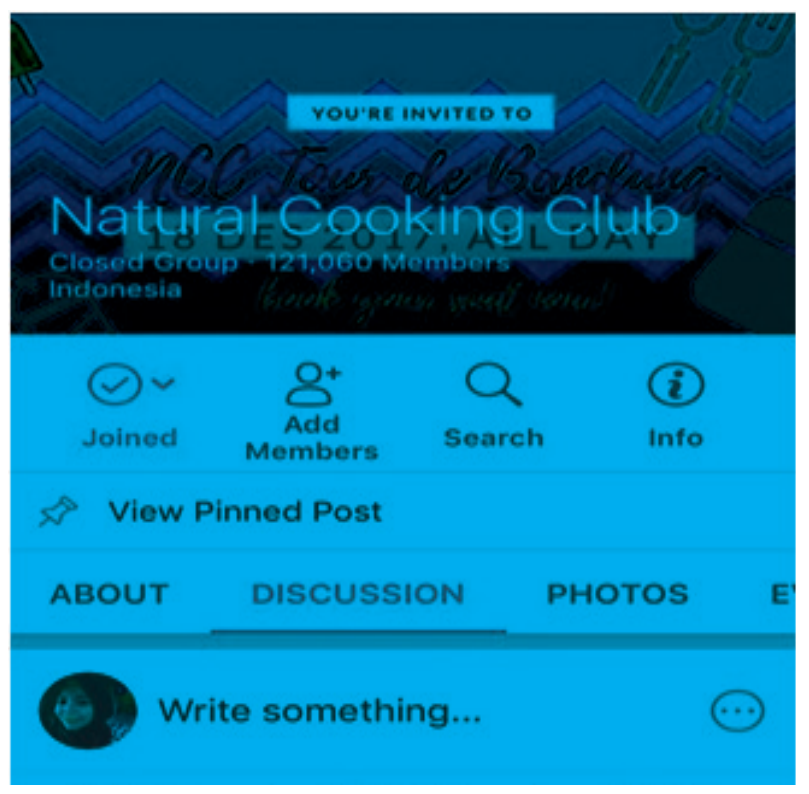

Sumber: Instagram, 2018

\section{Gambar 5 Group Natural Cooking Club di Facebook}


Zinaida (2016) dalam jurnalnya mengenai upaya pengenalan produk kuliner lokal memlalui bauran komunikasi pemasaran digital, mengungkapkan bahwa terdapat beberapa hal penting yang dilakukan dalam beriklan di media sosial Facebook antara lain: 1). melihat target market yang benar. Kesalahan utama pebisnis yang menggunakan iklan di media sosial adalah salah menentukan target yang sesuai dengan kriteria jenis produk yang dijual. 2). melakukan tes landing pages. Promosi yang besar tidak menjamin profit yang besar juga, harus dilakukan tes terlebih dahulu mulai dari budget promosi iklan yang kecil terlebih dulu baru dapat melakukan promosi dengan kapasitas besar ke landing pages yang ada di dalam Facebook pages. 3). menggunakan sponsored story. Traffic di Facebook dapat dengan mudah dijangkau calon pembeli apabila diceritakan dalam sponsored story.

Promosi yang dilakukan Kika's Catering melalui Instagram dan Facebook adalah bagian dari bauran pemasaran digital, yang menjadi teknik pemasaran modern dan popular saat ini. Dalam pemasaran digital, memungkinakan calon konsumen memiliki waktu yang lebih dan kebebasan untuk mencari tahu dan membaca detail produk yang dipasarkan. Berbeda dengan pemasaran konvensional, setiap bentuk promosi yang diberikan seperti brosus dan lain sebagainya seringkali terbuang percuma, tentunya menajdi pengeluaran yang cukup besar. Kehadiran pemasaran digital mampu meminimalisir kendala-kendala tersebut. Untuk mencapai keberhasilan dalam pemasaran digital, pesan yang disampaikan harus disesuaikan dengan target market dan peristiwa yang menjadi tren saat ini. Maka sukses atau tidaknya pemasaran digital terletak pada isi pesan (konten) yang diberikan (Salman \& Candrasari, 2016).

\section{SIMPULAN}

Digital marketing atau yang lebih dikenal dengan istilah e-marketing, merupakan bentuk usaha dari pemasar untuk memasarkan produk dan jasanya serta membangun relasi dengan konsumen melalui media Internet. Terdapat beberapa hal yang harus menjadi perhatian dalam melakukan kegiatan promosi digital, yaitu mendefinisikan target konsumen dengan jelas, dan penggunaan konten promosi. Konten promosi digital untuk bisnis kuliner yang tepat digunakan di media sosial Instagram adalah konten visual/image dan hashtag. Sedangkan untuk media sosial Facebook adalah konten photo album, teks, dan fanpage.

Berdasarkan hasil penelitian yang ada, maka peneliti menyarankan bagi pebisnis online yang memanfaatkan media digital atau sosial media dalam melakukan kegiatan promosi, agar terlebih dahulu memahami karakteristik 
audience yang menjadi konsumen, selanjutnya memaksimalkan konten yang berbeda untuk setiap jenis media sosial, karena setiap media sosial memiliki keunggulan dan kelemahan masing-masing dalam mewadahi konten promosi.

\section{DAFTAR PUSTAKA}

Adam, A. (2014). Culture and social media: an elementary textbook. Cambridge: Scholar Publishing.

Aljawiy, A. Y. \& Muklason, A. (2011). Jejaring sosial dan dampak bagi penggunanya. Program studi Sistem Informasi Unipdu, Jombang. Jurnal Ilmiah "Teknologi”.

Basrowi. (2008). Memahami penelitian kualitatif. Jakarta: Rineka Cipta.

Biagi, S. (2005). Media impact an introduction to mass media (7th ed). California: Thomas Wadsworth.

Boone, L. E. \& David L. K. (2005). Contemporary marketing. Thomson South Western, Ohio, USA.

Darmawan. (2015). Content marketing: panduan pemula dalam melakukan pemasaran konten.www.panduanim.com/ content-marketing/diakses pukul 06:25 WIB pada hari Kamis, 25 Januari 2018.

Emarketer diakses dari https://www. emarketer.com/Article/IndonesiaFacebook-Remains-Most-Popular-SocialSite/1014126.

Fajarini, S. D. (2016). Efektivitas penggunaan aplikasi instagram sebagai media komunikasi pemasaran bisnis online shop. Universitas Bengkulu.

Flew. (2005). New media: an introduction. 2nd edition. New York: Oxford University
Press.

Gustam, R. R. (2015). Karakteristik media sosial dalam membentuk budaya populer korean pop di kalangan komunitas samarinda dan balikpapan. eJournal Ilmu Komunikasi.

Hughes, C. (1999). The relationship of use of the internet and loneliness among college students. Boston College.

Jauhari, J. (2014). Upaya pengembangan usaha kecil dan menengah (ukm) dengan memanfaatkan e-commerce. Jurnal Sistem Informasi, 2 (1).

Juju, D.\& Feri, S.(2010). Branding promotion with social networks. Jakarta: Elex Media Komputindo.

Kaplan, A. M. \& Haenlein, M. (2010). Users of the world, unite! the challenges and opportunities of social media. Business Horizons.

Kotler, P. \& Amstrong, G. (2008). Prinsipprinsip pemasaran. Jilid 1. Jakarta: Erlangga.

Lasmadiarta, M. (2011). Extreme facebook marketing for giant profits. Jakarta: Elex Media Komputindo.

Listiani, E. (2016). Peran instagram dalam pemasaran bagi dunia usaha. Pangkalpinang: Prosiding The Power of Communication Conference 2016.

Mc. Quail, D. (1987). Teori komunikasi massa. Jakarta: Erlangga.

Mulyana, D. (2000). Ilmu komunikasi: suatu pengantar. Bandung : Remaja Rosdakarya.

Pengguna media sosial aktif di dunia tahun 2015. diakses dari http://wearesocial.sg.

Prihantoro, E. (2016). Akun instagram dagelan sebagai media promosi brand dan bisnis lokal indonesia. pangkalfinang: Prosiding The Power of Communication Conference 2016.

Purwanto, J. (2006). Komunikasi bisnis. Jakarta: 
Erlangga.

Rakhmat, J. (2002). Metode penelitian komunikasi. Bandung: Remaja Rosdakarya.

Saepudin \& Darmawati, W. (2016). Penggunaan media sosial twitter dalam pembentukan dimensi ekuitas merek l-men. pangkalpinang: Prosiding The Power of Communication Conference 2016.

Salman \& Candrasari, S. (2016). Perilaku pembelian pada komunikasi pemasaran digital.pangkalpinang: Prosiding The Power of Communication Conference 2016.

Scott, D. M. (2010). New rule of marketing and pr: how to use social media, blogs, news releases, online video, and viral marketing to reach buyers directly.

Strauss, J. \&Raymond, F. (2001). E-marketing. second edition. Englewood Cliffs: Prentice Hall.

Zarela, D. (2010). The social media marketing book. Canada: O'Reilly Media Inc.

Zinaida, R. S. (2016). Upaya pengenalan produk kuliner lokal melalui bauran komunikasi pemasaran digital. Pangkalpinang: Prosiding The Power of Communication Conference 2016. 